\title{
TEKNIK BUDIDAYA TANAMAN TOMAT CHERRY (Lycopersicum Cerasiformae Mill ) DI GAPOKTAN LEMBANG JAWA BARAT
}

\author{
Nurnita Sari ${ }^{1}$, Aditya Murtilaksono ${ }^{2}$ \\ 1,2Jurusan Agroteknologi Fakultas Pertanian Universitas Borneo Tarakan \\ Jalan Amal Lama Nomor 1 Kelurahan Pantai Amal, Kota Tarakan, 77123 \\ Email : nithasarii160@gmail.com
}

Receive: 25 September 2018

Accepted: 10 Oktober 2018

\begin{abstract}
Tomato is a type of vegetable that has several varieties, one of which is a type of tomato cerasiforme (Dun.) Alef. Known as cherry tomatoes which have the characteristics of small and round fruit. Lower tomato production in Indonesia instead of varieties that are not planted are suitable, technical culture is not good, and the conversion of agricultural functions that use agricultural land is increasingly limited. To approve the results of production and community needs for a good tomato plant then began to be asked to cherry tomato planting techniques in Gapoktan Lembang Agri. The research method began with processing, planting, maintenance, harvesting to post-harvest. The results of the Gapoktan Lembang Agri West Java research application of cultivation techniques of cherry tomato plants that produce quality cherry tomatoes are marketed overseas such as Singapore
\end{abstract}

Keywords : Tomato, West Java, Harvest, Post Harvest

\begin{abstract}
ABSTRAK
Tomat merupakan jenis sayuran buah yang memiliki beberapa jenis varietas salah satunya yaitu jenis varietas tomat cerasiforme (Dun.) Alef. Dikenal dengan tomat cherry yang memiliki ciri khas berbuah kecil dan bulat. Rendahnya produksi tomat di Indonesia diduga disebabkan varietas yang ditanam tidak cocok, kultur teknis yang kurang baik, serta alih fungsi lahan pertanian yang menyebabkan lahan pertanian semakin sempit. Untuk memenuhi hasil produksi dan kebutuhan masyarakat akan tanaman tomat yang baik maka mulai dilakukannya penerapan teknik budidaya tomat cherry di Gapoktan Lembang Agri Jawa Barat. Metode penelitian yaitu mulai dengan melakukan pengolahan lahan, penanaman, pemeliharan, panen hingga pasca panen. Hasil penelitian Gapoktan Lembang Agri penerapan teknik budidaya tanaman tomat cherry yang baik menghasilkan tomat cherry yang berkualitas yang dipasarkan hingga ke luar negeri seperti Singapura
\end{abstract}

Kata Kunci : Tomat, Jawa Barat, Panen, Pasca panen

\section{PENDAHULUAN}

Gapoktan Lembang Agri yang berada di Desa Cikidang Kecamatan lembang Kabupaten Bandung Barat. Kelompok tani yang tergabung dalam Gapoktan ini terdiri dari 8 kelompok tani dan satu kelompok wanita tani dengan total anggota 203 orang. Kawasan pertanian yang ada memiliki luas lahan pertanian 110 ha, dari luasan lahan terdapat berbagai komoditas seperti brokoli, lettuce head, baby buncis, cabai, sawi, terong, zukini, kaboca, dan tomat cherry.

Tomat merupakan jenis sayuran buah yang memiliki beberapa jenis varietas salah satunya yaitu jenis varietas tomat cerasiforme (Dun.) Alef. Dikenal dengan tomat cherry yang memiliki ciri khas berbuah kecil dan bulat (Pracaya, 1998). Kesadaran masyarakat terhadap nilai kesehatan menjadikan tomat sebagai sumber nutrisi dan antioksidan yang sangat dibutuhkan. Tomat Cherry banyak diminati karena mengandung kadar protein, lemak, serat, energi, vitamin A dan vitamin $\mathrm{E}$ lebih tinggi serta rasa yang lebih manis dan segar dari tomat biasa (Tugiyono 2005).

Menurut data Badan Pusat Statistik (BPS) tahun 2015, produksi tomat di Jawa Barat mencapai 296.217 ton/tahun. Sedangkan pada tahun 2014, produksi tomat di Jawa Barat mencapai 304.687 ton/tahun. Berdasarkan data tersebut dapat dilihat adanya penurunan produksi tomat di Indonesia. Tingginya permintaan terhadap tomat cherry hanya dapat dipenuhi $0,6 \%$ oleh produksi dalam negeri, sehingga sisanya masih harus diimport hingga senilai US $\$ 12.148 /$ tahun. Rendahnya produksi tomat di Indonesia diduga disebabkan varietas yang ditanam tidak cocok, kultur teknis yang kurang baik, serta alih fungsi lahan pertanian yang menyebabkan lahan pertanian semakin sempit (Wijayani, Wahyu 2005).

Untuk memenuhi hasil produksi dan kebutuhan masyarakat akan tanaman tomat yang baik maka mulai dilakukannya penerapan teknik budidaya tomat cherry. Tujuan penelitian ini 
adalah ingin mempelajari cara membudayakan tomat cherry di Gapoktan Lembang Agri

\section{METODE DAN BAHAN}

Penelitian ini dilaksanakan di Gapoktan Lembang Agri Jawa Barat. Alat dan bahan yang digunakan adalah benih Tomat Cherry, pupuk kotoran ayam dan pupuk mutiara, cangkul, kayu ajir, tali rapia, mulsa, meteran, gembor. Metode dalam pengumpulan data ini menggunakan survey sederhana, partisipasi aktif dan juga melakukan wawancara langsung dengan petani. Kegiatan yang dilakukan di Gapoktan Lembang Agri Jawa Barat seperti melakukan pengolahan lahan, pembuatan bedengan, pemupukan dasar, pemasangan mulsa, penanaman, pemeliharan meliputi penyiraman,pemupukan susulan, pemberian ajir, pemangkasan, penyiangan gulma, dan pengendalian hama dan penyakit, panen dan pasca panen.

\section{HASIL DAN PEMBAHASAN}

Tomat cherry secara umum dapat ditanam di dataran rendah, medium, dan tinggi, tergantung varietasnya. Tomat Cheery yang ditanam dataran tinggi yang sejuk dan kering akan menghasilkan buah yang lebih baik jika ditanam di dataran rendah dan medium. sebab tomat tidak tahan panas terik dan hujan. Suhu optimal untuk pertumbuhannya adalah $23^{\circ} \mathrm{C}$ pada siang hari dan $17^{\circ} \mathrm{C}$ pada malam hari. Suhu di atas $270 \mathrm{C}$ akan menghambat pembentukan buah dan pertumbuhan tomat (Yamin 2012). Tomat cherry memerlukan curah hujan 750-1250 mm per tahun dan cahaya sinar matahari kisaran minimal 8 jam per hari (Rubazky, Yamaguchi 1999). Wiryanta (2004) menyebutkan bahwa keadaan temperatur dan kelembaban yang tinggi, akan berdampak kurang baik terhadap pertumbuhan, kualitas buah dan produksi tomat cherry. Salah satu tempat budidaya tanaman tomat Cherry di dataran tinggi adalah Gapoktan Lembang Agri.

Gapoktan Lembang Agri merupakan salah satu pusat penanaman tanaman hortikultura. Salah satu tanaman hortikultura yang ditanam di Gapoktan Lembang Agri adalah tanaman tomat cherry. Tanaman tomat cherry merupakan salah satu jenis tanaman tomat yang memiliki ukuran yang kecil. Budidaya tanaman tomat cherry sama seperti tomat pada umumnya dimulai dari persemaian benih, persiapan lahan, pemeliharaan, panen dan pasca panen

\section{Persemaian Benih}

Tanaman tomat cherry merupakan tanaman yang memiliki benih yang harus disemai terlebih dahulu hingga menjadi bibit.. Semai ini bertujuan agar tanaman tomat dapat lebih kuat ketika dipindahkan ke bedengan karna sudah menjadi bibit yang memiliki morfologi yang kuat ketika berada di lahan.

Penyemaian dilakukan dengan cara benih disebarkan pada tempat yang telah diberikan pupuk, setelah itu di tutup dengan menggunakan karung yang bertujuan agar kondisi tempat semai tersebut selalu lembab, lalu didiamkan selama 10 hari. Setelah itu, bibit yang berumur 10 hari tersebut dipindahkan ke $\mathrm{x}$ tray yang merupakan wadah semai yang terbuat dari daun pisang yang kering yang telah diberikan pupuk. Bibit dipindahkan dan didiamkan selama 1 bulan hingga menjadi bibit yang sudah memiliki morfologi yang lengkap dan mampu bertahan ketika berada di lahan.

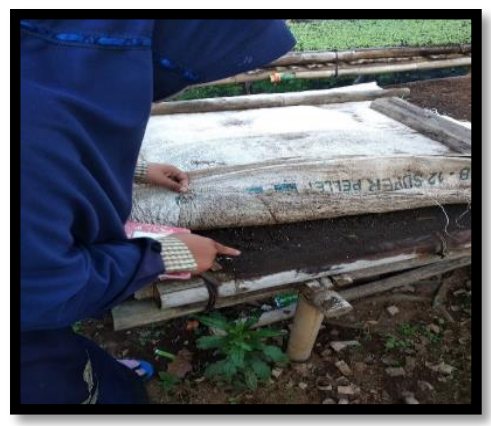

Gambar 1. Penyemaian Benih Tomat Cherry

\section{Persiapan Lahan}

a) Pengolahan Lahan

Lahan yang akan digunakan untuk ditanai tanaan tomat cherry terlebih dahulu harus di lakukan pengolahan lahan yaitu dengan cara dicangkul dengan kedalam 20-30 $\mathrm{cm}$. Tujuan dari pengolahan yaitu untuk memperbaiki struktur tanah,memperbaiki drainase dan aerase tanah kemudian kemudian meratakan tanah dan mengendalikan gulma sehingga tanaman dapat tumbuh dengan baik.

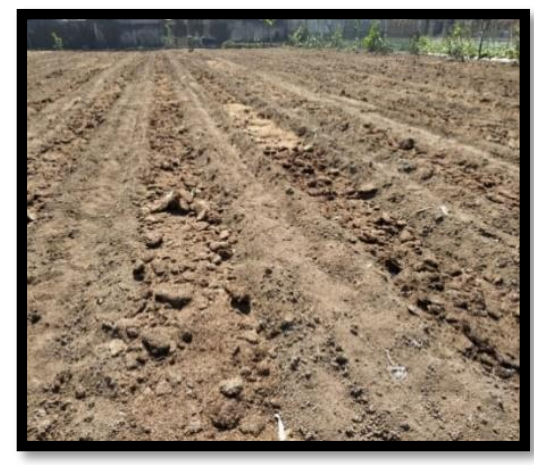


Gambar 2. Pengolahan Lahan Tanaman Tomat Cherry

b) Pembuatan Bedengan

Dalam pembuatan bedengan tanah dicangkul dengan kedalaman 40-50 cm kemudian dibentuk bedengan dengen lebar $100 \mathrm{~cm}$, tinggi bedengan $35 \mathrm{~cm}$,panjang bedengan $90 \mathrm{~m}$ dan jarak antar bedengan yaitu $20 \mathrm{~cm}$. Pembuatan bedengan bertujuan untuk menghindari lahan dari genangan air ketika lahan di guyur oleh air hujan dan untuk mempermudah dalam pengendalian gulma.

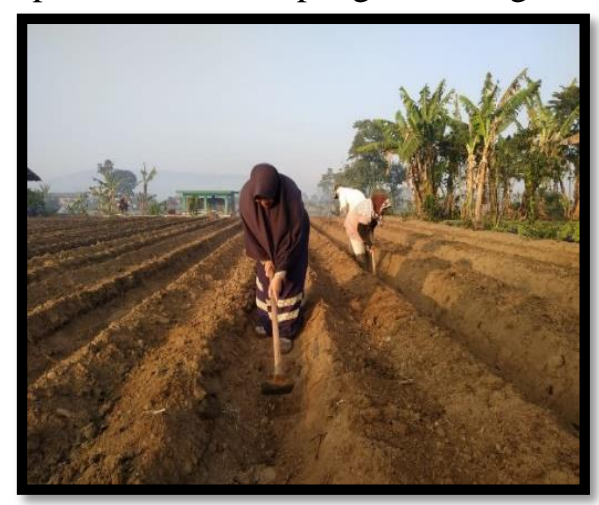

Gambar 3. Pembuatan Bedengan Tanaman Tomat Cherry

c) Pemupukan Dasar

Pemberian pupuk dasar bertujuan untuk memenuhi kebutuhan unsur hara yang dibutuhkan oleh tanaman agar pertumbuhannya optimal dan memperbaiki kondisi tanah. Pupuk yang digunakan yaitu pupuk kotoran ayam, pemupukan dasar ini dilakukan dengan cara disebar secara merata diatas permukaan bedengan.

Pupuk dasar yang telah diberikan dicampur sampai merata dengan menggunakan cangkul. Kemuduan tutup bedengan dengan tanah setebal $5-10 \mathrm{~cm}$ yang diambil dari kiri dan kanan bedengan sampai merata.

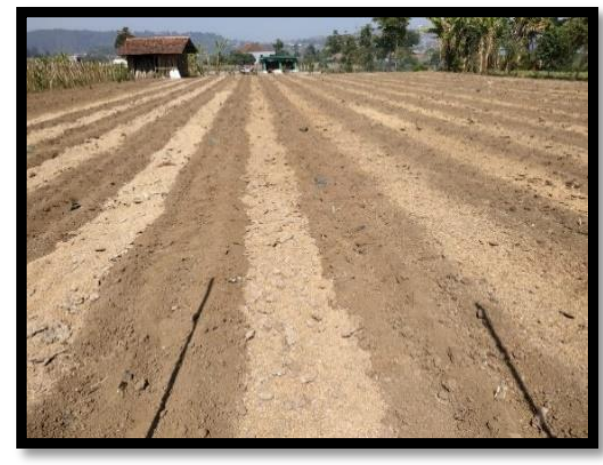

Gambar 4. Pemberian Pupuk Dasar Tanaman Tomat Cherry

\section{Penanaman}

a) Pemasangan Mulsa

Pemasangan mulsa bertujuan untuk mengurangi erosi tanah,menekan pertumbuhan gulma, menjaga kelembaban serta dapat mengurangi serangan hama. Pemasangan mulsa dengan cara:

1. Mulsa dibentangkan diatas bedengan, warna perak menghadap atas dan warna hitam menghadap tanah,siapkan bilah penjepit bambu dibentuk menyerupai huruf $U$.

2. Sisi mulsa (pinggi mulasa) ditarik kearah bawah hingga mengembang,kemudian cubit sedikit sisi mulsa dan gulungkan dengan bilah bambu penjepit serta patahkan dan tancapkan dimasing-masing sisi bedengan. Pemasangan bilah bambu dilakukan bertahap dari satu ujung ke ujung berikutnya

3. Dalam penggunaannya lembar mulsa dibentangkan dan dipotong dari pinggir panjang bedengan, hal tersebut dilakukan untuk mengantisipasi pemuaian pada mulsa

4. Lebar mulsa mempunyai ukuran lebar $100 \mathrm{~cm}$ dan panjang dipotong sesuai dengan ukuran bedengan.

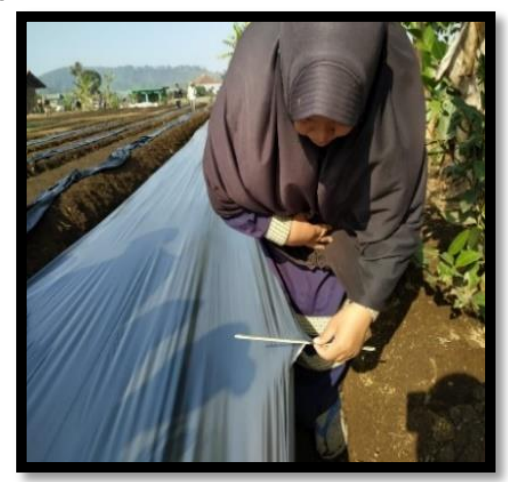

Gambar 5. Pemasangan Mulsa Tanaman Tomat Cherry

b) Penanaman

Penanaman dilakukan pada pagi hari atau sore hari agar mathari tidak terlalu terik. Penanam dilakukan dengan cara membuat lubang tanan disetiap lubang mulsa dengan kedalaman 2-5 cm lalu memindahkan benih dari tempat penyemaian ke lahan budidaya.

Penanaman bibit tomat sebanyak 1 bibit di setiap lubang tanam setelah bibit tomat dimasukkan ke dalam lubang tanam, tutup dengan tanah. Kemudian sira dengan air sehingga tanah menjadi basah, dengan tujuan 
untuk menjaga kelembaban tanah agar bibit dapat tumbuh.

\section{Pemeliharaan}

Pemeliharaan dapat menentukan hasil produksi yang diperoleh baik secara kualitas maupun kuantitas. Proses pemeliharan pada teknik budidaya tanaman tomat cherry sebagai berikut :

\section{Penyiraman}

Kegiatan penyiraman dapat dilakukan pada pagi atau sore hari. Kegiatan penyiraman juga tergantung kondisi tanah dan musim. Apabila musim hujan maka tidak perlu dilakukan penyiraman secara rutin maupun pada saat musim kemarau perlu dilakukan penyiraman secara rutin agar tanaman tomat mendapat keteredian air yang cukup.

2. Pemupukan Susulan

Kegiatan pemupukan dilakukan ketika bibit berumur 10 hari setelah pindah tanam dan diberikan lagi setelah berumur 10 hari setelah pemberian yang pertama. Prosedur pemupukan yaitu menggunakan pupuk NPK mutiara (16:16:16) dengan air bersih yang ditampung di dalam drum, kemudian dilakukan pengocoran ke dalam lubang tanam. Pengecoran pupuk NPK yang dilarutkan tersebut dilakuakn dengan menyemprotkan larutan pupuk kedalam setiap lubang tanam dengan tujuan agar proses penyerapan pupuk bagi tanaman menjadi optimal dan dapat terpenuhi unsur hara bagi tanaman tomat cherry.

3. Tanaman tomat cherry memerlukan ajir ketika tanaan sudah besar, ajir sudah dipasang ketika tanaman tomat cherry berumur 40 hari setelah pindah tanam, dan batang pada tanaman tomat cherry diikat menggunkan tali rapia pada ajir agar tidak mudah jatuh.

4. Pemangkasan dilakukan dengan mengunakan gunting dan memakai sarung tangan, pemangkasan dilakukan dengan memangkas daun dan batang yang rimbun,rusak dan yang terserang oleh hama penyakit. Pemangkasan dilakukan seminggu $2 \mathrm{x}$ dengan tujuan agar tanaman tidak terlalu rimbun dan untuk mempermudah ketika dalam proses pemeliharan hingga pemanenan.

\section{Penyiangan}

Kegiatan penyiangan tidak sering dilakukan, karna lahan yang ditanami tomat cherry sudah menggunkan mulsa. Pengunaan mulsa dapat membantu dala pengendalian gulma dan menekan pertumbuhan gulma. Kegiatan penyiangan tetap dilakukan dengan membersihkan gulma disekitar tanaman.

6. Pengendalian Hama Penyakit

Pengendalian hama dan penyakiit perlu dilakukan, agar kualitas dan kuantitas tanaman yang diperoleh lebih optimal dan sesui dengan yang diharapkan. Hama dan penyakit merupakan salah satu faktor yang membatasi dan menghambat peningkatan produksi ataupun pertumbuhan tanaman.

Hama yang sering menyerang tanaan tomat cherry yaitu lalat buah sedangkan penyakit pada tanaman tomat cherry yaitu penyakit embun tepung. Pengendalian hama yang dilakukan yaitu dengan menyemprotkan insektidida serta fungisida pada tanaman tomat cherry dan sedangkan dalam pengendalian penyakit embun tepung biasanya dengan larutan sabun yang disemprotkan pada daun yang terserang hal ini bertujuan agar pertumbuhan tanaman tidak terganggu serta aman dari serangan hama dan penyakit.

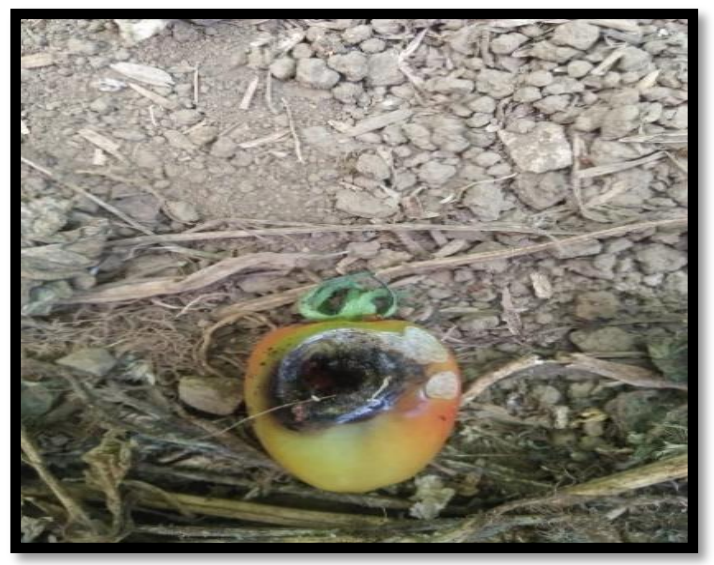

Gambar 6. Tomat Cherry Terkena Penyakit Antraknosa

\section{Panen dan Pasca Panen}

\section{Panen}

Tanaman tomat cherry dapat dipanen ketika berumur 4-6 minggu. Kegiatan panen dilakukan pada pagi hari, hal tersebut bertujuan untuk mengurangi penguapan. Panen dapat dilakukan dengan cara memetik tomat cherry yang berwarna merah atau berwarna kuning keorenan, memetik dengan cara perlahan agar tomat yang masih berwarna hijau tidak telepas dari tangkai dan tidak menimbulkan kerugian bagi petani. 


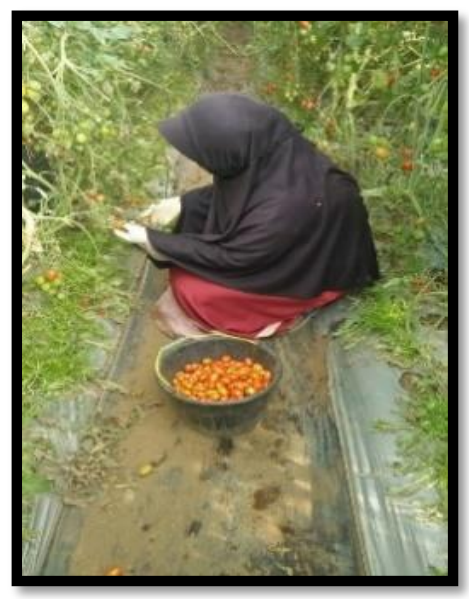

Gambar 7. Panen Tomat Cherry

2. Pasca Panen

Kegiatan pasca panen adalah bentuk kegiatan lanjutan setelah proses pemanennan tomat cherry. Berikut ini adalah proses penanganan pasca panen tomat cherry :

a) Pernyortiran

Proses penyortiran adalah kegiatan memisahkan tomat cheery yang berukuran sedang dan kecil dan tomat cherry yang rusak akibat terserang hama ataupun penyakit. Tujuan dari proses penyortiran untuk memastikan bahwa tanaman tomat cherry yang akan dipasarkan tersebut harus berkualitas baik dan memenuhi kriteria.

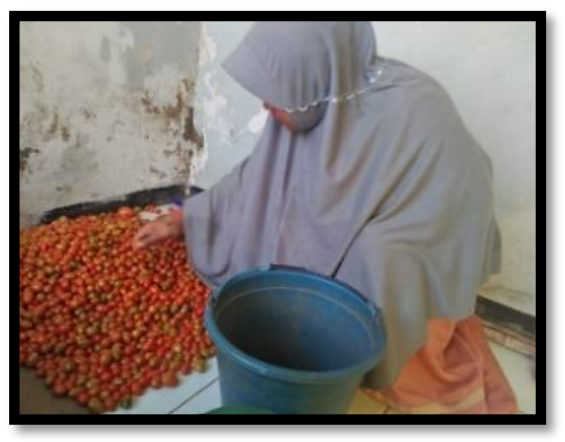

Gambar 8. Penyortiran Tomat Cherry b) Pengemasan
Tomat cherry yang sebelumnya sudah melewati tahap penyortiran selanjutnya dikemas menggunakan karung kemudian dipasarkan ke restoran dan super market.

\section{KESIMPULAN}

Penelitian ini dapat memberikan pengetahuan serta wawasan mengenai penerapan teknik budidaya tomat cherry yang diterapkan di tempat tersebut mulai dari bagaimana proses penyemaian benih,persiapan media tanam hingga tomat cherry tersebut dipasarkan kepada konsumen.

\section{UCAPAN TERIMA KASIH}

Ucapan terima kasih disampaikan bapak Aditya murtilaksono atas bantuan dan arahannya sehingga penulis dapat menyelesaikan tulisannya.

\section{DAFTAR PUSTAKA}

Badan Pusat Statistik. 2015. Data Produksi Tomat.

Diakses dari http://www.bps.go.id.

Pracaya. 1998. Bertanam Tomat. Kanisius; Yogyakarta.

Rubatzky, V. E. dan M. Yamaguchi. 1999. Sayuran Dunia 3 Prinsip, Produksi, dan Gizi. Penerbit ITB. Bandung

Tugiyono. 2005. Tanaman Tomat. Agromedia Pustaka. Jakarta

Widodo W. dan A. Wijayani, 2005. Usaha meningkatkan kualitas beberapa varietas tomat dengan system budidaya hidroponik. Ilmu Pertanian 12 (1): 77 - 83 .

Wiryanta, W.T.B. 2004. Bertanam Tomat. Agromedia Pustaka. Jakarta.

Yamin, A. 2012. Analisis Resiko Produksi Tomat Cherry Pada Daerah Pacet SegarKecamatan Cipanas Kabupaten Cianjur, Provinsi Jawa Barat. Skripsi. Institut Pertanian Bogor, Bogor. Diakses darihttps://repository.ipb.ac.id/jspui/bitstream/ 123456789/60836/10/H12aya.pdf 